\title{
頸椎症性脊髄症に対する片開き式頸椎管拡大術について
}

\author{
谷島健生吉益倫夫少粥 正 博
}

\section{Results of an Expansive Laminoplasty with a Unilateral Opening for Treating a Cervical Spondylotic Myelopathy: A Postoperative Evaluation of Twenty-five Patients \\ by}

Takeo Tanishima, M.D., Norio Yoshimasu, M.D., and Masahiro Ogai, M.D.

from

Department of Neurosurgery, Tokyo Kosei-nenkin Hospital

The results of an expansive laminoplasty with a unilateral opening have been evaluated in 25 patients with cervical spondylotic myelopathy caused by a narrowed canal and/or multisegmental spondylosis.

At one year postoperatively, drilled and hinged laminae showed sufficient bony consolidation for stabilizing the posterior spinal structure in all patients. However, in 3 patients the laminae were inadvertently separated from the lateral mass of the vertebrae during their hinging and had dislocated into the spinal column. Even so, this dislocation had no adverse effect on the patients' neurological conditions and six months after the laminoplasty, a spontaneous reduction was noted with a definite bony fusion. Further, at six months postoperatively, a slightly kyphotic deformity occurred in 2 patients, but no further deformity developed in these patients and the spinal column remained unchanged and no neurological dysfunctions that could be ascribed to this deformity were manifested. In 20 patients the neurological conditions exhibited an improvement, whereas in 4 patients no change was seen, although all 4 patients had shown atrophy of the spinal cord. Finally, 1 patient developed a C5 nerve dysfunction, which was presumably caused by the tethering of the posteriorly shifted cord following decompression.

Based on these findings, it thus was concluded that an expansive laminoplasty with a unilateral opening is a safe and reliable procedure for cases manifesting a cervical spondylotic myelopathy due to a narrowed canal and/ or multisegmental spondylosis.

(Received January 19, 1994 ; accepted August 31, 1994)

Key words : laminoplasty, open-door laminoplasty, cervical spondylotic myelopathy, cervical spondylosis

Jpn J Neurosurg (Tokyo) $4:$ 151-156, 1995

\section{はじめに}

頸椎症性脊髄症（頸髄症）に対する術式として前方法 と後方法があり，どちらを選択するかは議論の多いとこ ろである115)23)25)。一般的には病変が 3 椎間以上に及び， 特に頸椎管狭窄症を合併した場合には，後方除圧術を選 択することが多いように思われる。この後方除圧術とし て古くから椎弓切除術が行われてきたが，術後に後方支
持組織を欠くために不安定性を生じたり，外傷に対する 易損傷性が増すなどの欠点が指摘されてきた ${ }^{3224)}$ 。これ らの欠点を補うために近年，後方支持組織としての椎弓 を温存する椎弓形成術（頸椎管拡大術）が主として日本 の整形外科医により種々開発されてきた8)〜11).これらの 形成術のなかで片開き式拡大術は, 脳神経外科医には馴 染みが薄いが, 1978 年に発表された比較的古い方法では ある ${ }^{4)}$.特にその簡便性, 安全性において他の術式より優

東京厚生年金病院脳神経外科 / $~ 162$ 新宿区津久戸町 5-1〔連絡先：谷島健生〕

Address reprint requests to : Takeo Tanishima, M.D., Department of Neurosurgery, Tokyo Kosei-nenkin Hospital, 5-1

Tsukudo-cho, Sinjuku-ku 162, Tokyo, Japan 

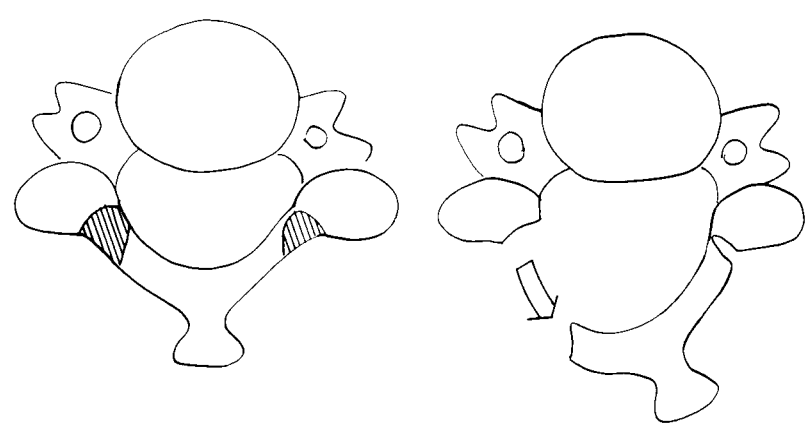

Fig. 1 Schematic illustrations depicting a unilateral open laminoplasty

The hatched areas indicate the sites of drilling.

\section{れているとの評価が高い.}

われわれは最近, 積極的にこの片開き式拡大術を用い てきたが，その有効性を確認できたのでここにその経験 を報告したい。特に今回は術式に注目し，術後の1）骨 癒合, 椎弓の安定性，2）椎弓の脊柱管内への落ち込み, 3 ）後彎変形の 3 点につき検討を加えた。

\section{対象と方法}

片開き式頸椎管拡大術は 1978 年平林ら ${ }^{4)}$ にり発表 された方法である. “open-door laminoplasty”として国 際的にも広く知られている . 術式は後方進入により両 側の椎弓根部, 椎間関節の内側 $1 / 3$ にエアードリルで側 溝を作り一側の側溝は切離し, 反対側の側溝を支点とし て椎弓を折り曲げるように持ち上げ靧椎管を抎大するも のである (Fig. 1)。この術式の特徵は, 棘突起緹割法など のように正中部でのドリリングがないことである．正中 部は一般的に脊髄の圧迫が一番強く，手術侵襲に弱いと ころである。したがって正中部でのドリリングがないと いうことは，それだけ安全であるといえる。また椎弓を 持ち上げるだけで移植骨を用いたり固定などの操作がな いのでより簡便な術式といえる．欠点としては開けた椎 弓が戻ってしまったり, 蝶つがい側の椎弓が脱落して脊 柱管内に落ち込んでしまうことなどがあるとされてい る.種々の変法が提案されている. 開けた椎弓部に移植 骨を置いたり，後側方固定を併用したりする方法などで ある゙?。

われわれは特に変法を用いず，ほほ原法通りの方法を 用いている．棘突起に関しては当初はすべて切除してい たが，棘突起の果たす制動的役割を重視して，現在では できるだけ棘間勒帯とともに残すようにしている。しか し上端と下端では黄勒帯の切開などの手術操作がしやす いように棘突起の一部を切除した。1993 年10月までに 25 例の頸椎症に対しこの術式を用いた。全例，頸椎症性

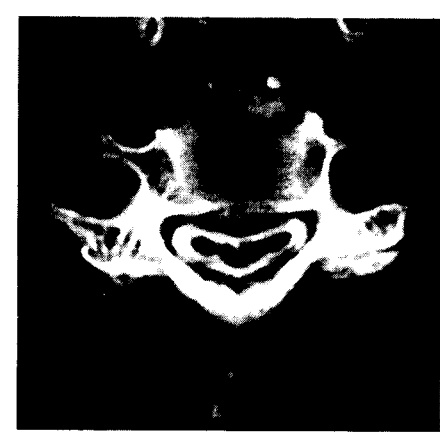

$\overline{\mathrm{A} \mid \mathrm{B}}$ Fig. 2 Preoperative (A) and postoperative (B) CT myelograms showing spinal cord atrophy in a 72-year-old woman

After the laminoplasty, the neurological conditions in patients with cord atrophy remained unchanged.
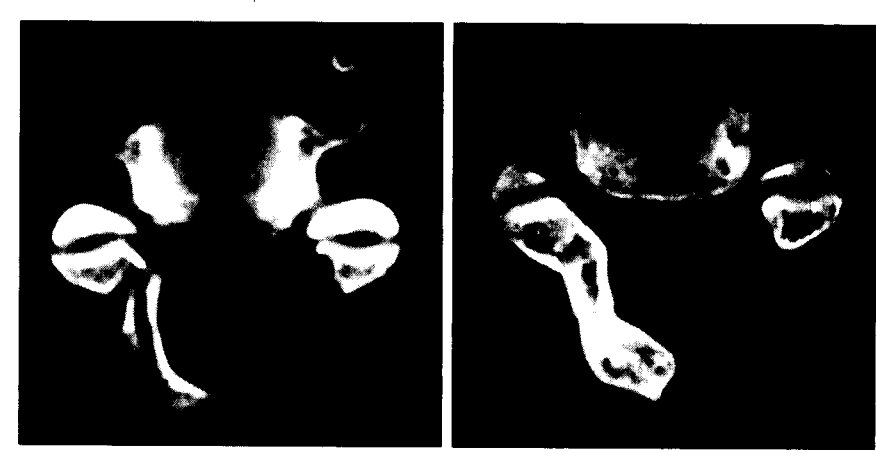

$\overline{\mathrm{A}} \mid \mathbf{B} \quad$ Fig. 3 CT myelograms of a 50 -year-old male demonstrating bony fusion on the hinged side of lamina at one month $(A)$ and at one year $(B)$ after the surgery

The lamina achieved sufficient bony consolidation for stabilization at one year postoperatively.

脊髄症であり，頸椎管狭窄症または多椎間病変である。

\section{結 果}

手術後, 自覚的あるいは他覚的な改善を示した良好例 は 20 例であり, 不変は 4 例, 新たな神経症状(上肢挙上 困難一C5 神経障害) が出現した症例が 1 例あった。手術 成績に関してはほぼ満足のいく結果であった。不変の 4 例はいずれも術前経過が長く, 画像検査では脊髄の萎縮 を示していた。しかし脊柱管の拡大は十分であり，手技 的問題はないものと思われた (Fig. 2). 唯一, 上肢挙上困 難の合併症をきたした症例は, 術前から後屈, 前彎が強 く, 後方除圧により脊髄の後方移動が強く起こり, 椎間 関節で神経根が圧迫を受けたものと思われる。これも片 開き式そのものの手技上の問題点はなかったと考えられ る.

\section{1. 椎亏の骨形成, 支持性について}

Fig. 3 は手術後 1 カ月と 1 年の頸椎の CT スキャンで 
$\overline{\mathbf{A} \mid \mathbf{B}}$
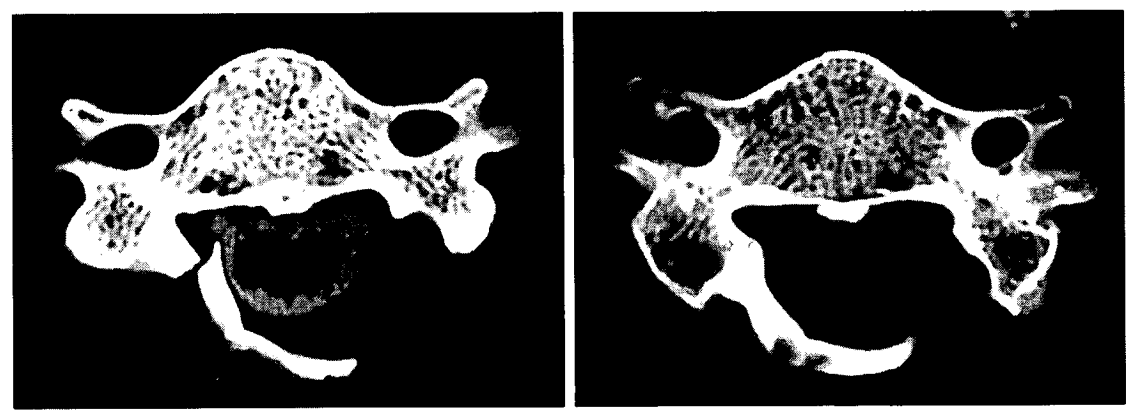

Fig. 4 CT myelograms of a 50-year-old male showing the dislocation of lamina into the spinal canal at one month after surgery $(\mathrm{A})$, and a spontaneous reduction with bony fusion that occurred 10 months after the surgery (B)

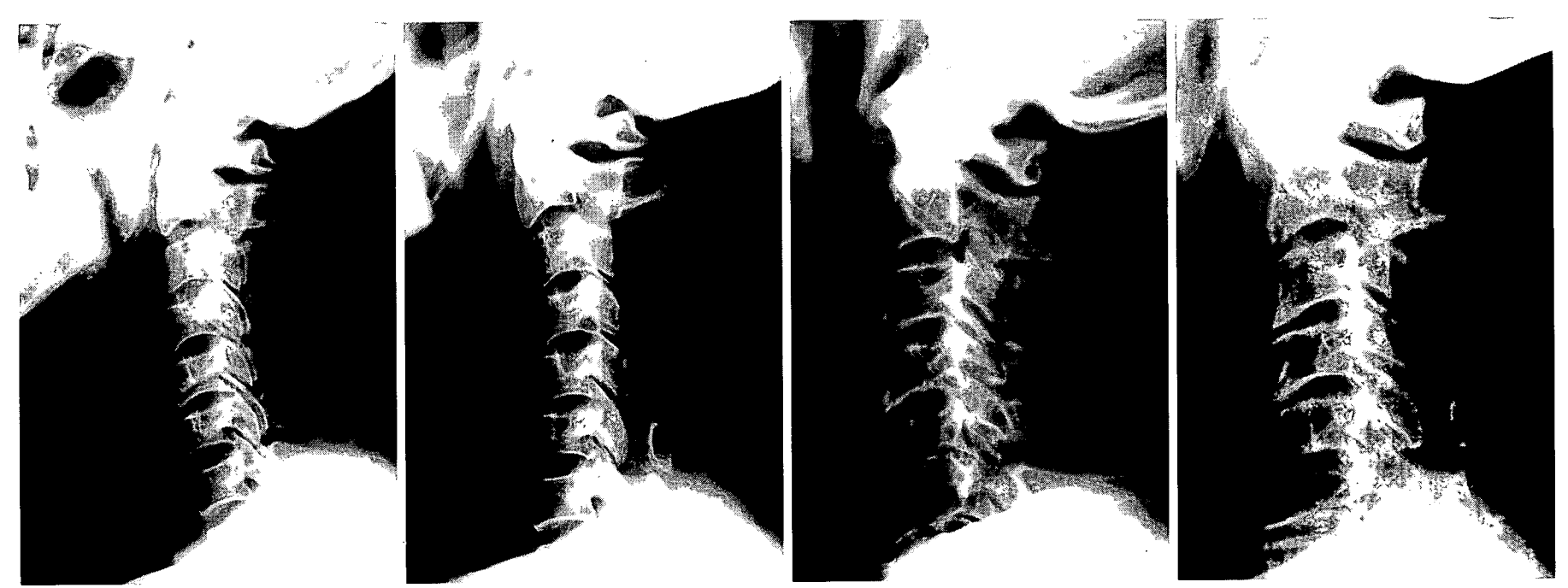

$\overline{\mathrm{A}|\mathrm{B}| \mathrm{C} \mid \mathrm{D}}$ Fig. $5 \quad \mathrm{X}$-ray photos of a lateral cervical spine in a 48-year-old male $(\mathrm{A}, \mathrm{B})$ and a 73 -year-old male $(\mathrm{C}, \mathrm{D})$

A, C : The preoperative photos show a loss of normal lordotic curvature.

B, D : The postoperative photos demonstrate a kyphotic deformity eight months after the laminoplasty.

ある、ほとんどの症例でこのように時間経過とともに蝶 つがい側のドリリング部には十分な骨形成がみられ，椎 弓の安定性，防護性にはまず問題ないものと思われた。

このように開大側に特に移植骨を用いないでも，椎弓の 支持性，防護性は十分に保たれていると思われる。

\section{2. 椎弓の替柱管内への落ち込み}

片開き式拡大術では蝶つがい側のドリリングは内側の 皮質骨を残し椎弓の連続性を保つことが必要であるが, 折り曲げる時に切り離されてしまい, 椎弓の断端が脊柱 管内に落ち込むことがある。このような症例が 3 例あつ た (Fig.4)。このために神経症状が出現した症例はな かった、しかし Fig. 4 にみられるように数力月後には落 ち込んだところも骨癒合し, 自然に整復されていた。こ のように多少落ち込んでも新たに神経症状をだすことは なく，時間経過とともに自然に整復されることが判明し た.

\section{3. 後彎变形}

後方手術の最大の欠点とされる術後の後彎変形につい て検討した。後彎変形は 25 例中 2 例に認められた。Fig. 5 はその 2 例の頸椎 $X$ 線撮影像である.それぞれ手術後 8 力月で後彎傾向を示していた $($ Fig. $5 \mathrm{~B}, \mathrm{D})$ ．この 2 例 とも術前から頸椎の直線化，軽い後彎傾向を示していた (Fig. 5A, C). また後彎が起こってくるのは第 2 頸椎と第 3 頸椎の間であり，第 3 頸椎以下の拡大術を行った部位 では配列に特に問題は生じていなかった。

\section{考察}

\section{1 前方接近法と後方接近法}

頸椎症性脊髄症の手術法として前方接近法と後方接近 法があり，どちらが有効であるかは古くから議論されて きた1) 15)23)25). 前方法は直接, 春髅の圧迫因子である骨棘 
を前から切除するため理に適っている。また不安定性の ある頸椎では強固な固定が得られるという長所をもって いる. しかし後方法に比べて術野が狭く，骨䊂の切除が 不十分となり脊髄除圧が不完全となることもある。これ に対し後方法は直接の前方圧迫因子は除去できないが, 術野も広く，比較的簡便で安全な方法といえる。しかし 後方支持組織を破壊するため, 術後の不安定性, 変形が 問題となる。 それぞれ長所・短所があり，どちらも症例 によっては有効であり，どちらかでなければならないと いう問題ではなく，われわれは術者の好みや習熟度によ り使い分ければよいと考えている。

一般的には 2 椎間までの病変で頸椎管狭窄症がなけれ ば前方法を，3椎間以上の病変で狭窄症を合併していれ ば後方法を選択することに問題はないであろう。しかし 実際には，2椎間病変があり中等度の狭窄症がある場合 など，前方法をとるか後方法をとるか迷うことが多い。 特に狭窄症の存在は重要で, 狭窄症があると前方除圧固 定しても数年後に再び金髄症を発症することがあること はよく知られている19121)。そういう点では後方除圧の方 が適応範囲は広いように思われる。われわれもどちらか というと後方法を積極的に採用してきた．特に狭窄症が 存在し画像上多椎間病変の場合には, 後方法はよい適応 と思われる。われわれの症例もほとんどがそのような病 態である。

\section{2 椎弓切除術亡椎弓形成術}

従来から後方除圧法として椎弓切除術が行われてき た.しかしこの椎弓切除術の問題点として，後方支持組 織の欠損のために時間経過とともに頸椎が前屈すなわち 後彎変形をきたしてくることが知られている20124)．また 椎弓切除後に硬膜外に肉芽組織が形成され，それが脊能有 を圧迫することがあるともいわれている．椎弓がないた め脊髄は外傷に対して損傷を受けやすく，軽微な外傷を 繰り返し受けやすいこともマイナス要因として指摘され ている3. これらは椎弓切除後に症状が再出現したり, 良 くならないことの原因ではないかとされてきた。これら の久点を改善するために，後方支持組織を温存する椎弓 形成術（頸椎管拡大術）が主として日本で開発されてき た ${ }^{8)}$-11). 椎弓形成術には棘突起緹割法 ${ }^{11)}$ などいくつかの 方法があるが,片開き式拡大術は 1978 年平林らにより発 表された方法である。その特徴はドリリングが両側のみ で正中部の操作がないことにある。一般的に頸椎管狭窄 症では脊髄の圧迫は正中部で一番強く，両側のくも膜下 腔は正中部に比べ比較的余裕があるのが普通である。し たがって正中部の操作がないということはより安全であ
り簡便であるといえる。ここに片開き式拡大術の一番の 特徴があるといえる。

そもそも椎弓形成術は椎弓切除術よりも手術成績が本 当によいのであろうか.このことに関してはっきりとし たデー夕を示している論文は少ない。むしろあまり変わ らないという報告がみられる ${ }^{16) 23)}$. 椎弓切除術では術後 の後彎変形の出現頻度が椎马形成術より高いことはよく 知られている20)。しかし後彎変形がきても，そのために 神経症状を出すことはほとんどないといわれてい る14)20)25).であるならばなぜ椎弓形成術なのであろう か.やはり理論的には形成術の方が優れているというこ とが，形成術が主流となっている理由であろう。いずれ にせよ治療成績において椎弓切除術と形成術では大きな 差はないのであるから，形成術をするにしてもあまり複 雑で risk を伴う術式は避けるべきである.形成術では外 側のドリリングが内側に寄ったり，椎弓フラップが落ち 込んだりすると頸椎管の拡大が不十分になることがあ る。複雑な形成術にこだわり，本来の目的である脊髄の 除圧が得られないのでは意味がない。この点に扔いて片 開き式拡大術のもつ簡便性，安全性は大きな魅力となつ ている。

今回の片開き式拡大術の経験から, 椎弓の支持性, 防 護性，骨形成は 1 年後くらいにはほとんど問題ないこと がわかった。片開き式は蝶つがい側のみで椎弓フラップ を支えるため，一見不安定にみえる。そのため開大側に 移植骨を置く術式も提案されている8).しかしわれわれ の経験では今回示したように特に移植骨を用いないで も，1 年もすると蝶つがい側には十分な骨形成が認めら れ，支持性，防護性はしっかりしたものとなっている. 移植骨の必要性はないといえよう。

\section{3 椎弓フラップの落ち込みと後彎变形}

片開き式椎弓形成術で一番問題となるのは, 椎弓フ ラップが蝶つがい側で切り離され脊柱管内に落ち込んで しまう場合があることである。われわれも 3 例にこのよ うな落ち込みを経験した。しかし脊髄を压迫し新たな神 経症状が出現した症例はなかった。神経症状を生ずるほ どの大きな落ち込みは起こらないものと思われる。また 切り離され落ち込んだ 3 例とも時間の経過とともに骨癒 合し，自然に整復位に戻っていた。多少の落ち込みはあ まり気にしなくても大文夫のようである。蝶つがい側の ドリリングの際，内側の骨皮質を削り切らないように残 すことがポイントであり，椎弓フラップを持ち上げる時 も切り離されないようにていねいにほどよく折り曲げる ことがコツである，落ち込みを経験した 3 例はいずれも 
初期の症例であり，手技に習熟して上記のような点に留 意してからは落ち込みの経験は皆無である。

術後の後彎変形は椎弓切除術では約 $20 \%$ に, 椎弓形成 術では約 $10 \%$ に生じるといわれている20). 今回の経験で も 25 例中 2 例 $(8 \%$ ）に認められた. 本来, 椎马形成術 が開発されてきた理由の一つが後彎変形の予防にあるわ けであるが，この術式では完全には予防できなかった。 後彎変形を生じた 2 例はいずれも術前から直線化, 若干 の後彎化が認められている。術前から頸椎の直線化があ る症例は，術後に後彎変形が生じやすいことはすでに報 告がある17)20)。このような症例に後方進入手術を行う場 合には術後に後彎変形が起こることを念頭において，術 後の固定装具などに細心の注意が必要と思われる．2例 とも後彎は術後半年位で認められ, それ以後は後彎は進 んでいない. 若年者では swan neck など程度のひどい 後彎変形が起こるが24), 高齢者ではある程度進むと変形 性頸椎症そのものが制動的に働き，あるところで変形が 止まるといわれている20).われわれの症例もそのような 見解を支持するものであった。また椎弓切除術のあと後 彎変形が起こったとしても，それによる神経症状の悪化 は認められないとする報告1420) があるが，われわれの症 例も神経症状の悪化はなく，従来の報告と合致する結果 であった。

興味あることは， 2 例とも第 2 , 第 3 頸椎間で屈曲し てきたことである。第 3 頸椎から第 7 頸椎の間では配列 の異常は生じなかった。これは一般的に第 3 頸椎椎弓は 第 2 頸椎椎弓の下にもぐりこんでいるため, それを持ち 上げるためには第 3 頸椎椎弓の上緑を一部削除しなくて はならないが，そのことと関係があるように思える．第 2 , 第 3 頸椎間の固定など術式に工夫が必要なように思 えた。一般的には後彎変形を防ぐために，後方支持組織 である C2 棘突起に付着する筋群の再縫合, 項勒帯の温 存7)，また制動的役割が大きい棘突起の保存などが提唱 されている。われわれもそのような手技を積極的に採用 して，後彎変形の予防に努めている．今回経験した 2 例 はいずれも初期の症例であり, 棘突起および棘間勒帯は 切除されている．最近の症例ではできるだけ棘突起を残 し，棘間勒帯も切除せずに行っているが，いまのところ 後彎変形をきたした症例はない。しかしこれだけで後彎 変形が防げるかどうかは長期にわたる観察が必要であ り，今後の課題と思われる.

\section{4 術後の症状}

手術後も症状の改善のみられなかった症例は 4 例あっ たが，これらはいずれも術前の経過が年単位と長く，術
後の画像検查では頸椎管の拡大は十分であったが，春䯣 の萎縮が著しく認められた。慢性的な圧迫により春髄の 局所的な萎縮をきたしたものと思われる．残存した症状 は自覚的なしびれ感が中心であった，脊髄の萎縮にまで 至った症例の症状改善が望めないことは明白であ り ${ }^{2)}{ }^{18)}$, 早期手術の必要性が示唆される結果であった。脊 髄機能の不可逆的な障害と MRI における $\mathrm{T}_{2}$ 強調画像 の高輝度信号との関連性は多くの報告がある ${ }^{13)}$ 。われわ れの 4 例もすべて術前の MRI 検査において局所的な高 輝度信号が認められた。手術しても症状の改善の得られ ない症例の多くは，このように MRI に打ける $\mathrm{T}_{2}$ 強調 画像の高輝度信号とともに脊髄萎縮が認められることを 強調したい.

\section{5 術後の筋力低下}

頸椎の手術後に上肢が側方に挙上できなくなる，すな わち三角筋を中心とした筋力低下をきたす合併症が最近 注目されている。これは前方除圧, 後方除圧いずれでも 起こり得ることが知られている. 文献的には前方除圧固 定術後では数\%に, 後方除圧術後では $10 \%$ 前後に起こる とされている12). 後方除圧術後の方がやや頻度が高いよ うである.C5 の前角細胞障害すなわち脊髄症であるとす る説と，神経根障害すなわち根症であるとする説がある が，後者とする意見の方が多い．原因に関しては大別し て2つの考えがある.1つは手術操作による神経根また は前角に対する損傷であるとする考元，もう1つは除圧 術後に脊髄の移動が起こり, それに伴い神経根に牽引力 (tethering) が加わり麻痺が生ずるとする考えである.ま た C5 神経の特異性も問題にされている。すなわち C 5 神 経支配筋 (三角筋) では他神経との吻合が少なく単独麻 痺になりやすい, C5 神経根は脊髄より出たあとほほ横走 するため，他の神経より短く脊髄の後方移動に対し余裕 がない.C5 神経根が通る椎間関節は他に比べ前方にあ り，椎間孔が狭い．そのため根の後方移動に対し損傷を 受けやすいなどである(622)。

われわれの経験した 1 例は術前より後屈, 前彎が強く それだけ後方除圧術後に後方移動が大きかったものと思 われる。また開大側で麻脾を生じていること，ドリリン グがやや外側であったことから，椎間孔での神経根の損 傷も十分考えられる。これ以降, 椎弓を切離する際, 必 ず手術用顕微鏡を使用し，手術操作による硬膜管の圧迫 を最小限にすること, 狭い椎間孔での神経損傷を避ける ためケリソンロンジュールを使用せず，先端の小さなダ イヤモンドバーにて切離すること,などを心がけている. そのようにしてからは, C5 神経麻痺は 1 例も経験しなく 
なった。頸椎手術の際にはつねにC5 神経麻痺が起こり 得ることを念頭において細心の注意が必要と思われる。

本論文の要旨は第 13 回日本脳神経外科コングレス（1993 年 5 月, 福島）において発表した。

\section{文 献}

1) Epstein JA: The surgical management of cervical spinal stenosis, spondylosis, and myeloradiculopathy by means of posterior approach. Spine 13:864-869, 1988.

2) Hayashi H, Okada K, Hashimoto J, Tada Kं, Ueno R : Cervical spondylotic myelopathy in the aged patient. A radiographic evaluation of the aging changes in the cervical spine and etiologic factors of myelopathy. Spine 13:618-625, 1988.

3）平林 洌，佐々木正，竹田 毅：頸部椎間板症の予後に ついて。中部整災誌 15：786-788，1972.

4）平林 洌：頸髄症に対する後方除圧法としての片開き式 頸部脊柱管拡大術について.手術 32：1159-1163, 1978.

5) Hirabayashi K, Watanabe K, Wakano K, Suzuki N, Satomi K, Ishii Y : Expansive open-door laminoplasty for cervical spinal stenotic myelopathy. Spine 8:693-699, 1983.

6) 平林 洌：頸部脊柱管抾大術一その評価と批判，津山直 一監修：頸椎腰椎外科, 東京, 南光堂, 1990, pp. 107-120.

7）星野雄一，黒川高秀，町田秀人，大西五三男，栗林義昭， 星地亜都司，侭田敏且，税田和夫：棘突起縦割法椎弓形 成術の長期成績. 臨整外 27：257-262，1992。

8）伊藤達雄, 过 陽雄：En-bloc 方式による頸部脊柱管拡 大術。別冊整形外科 No. 2, 1982, pp. 241-248.

9）岩崎洋明, 横田英麿, 石井元章, 植田百合人, 藤井繁昌, 神原幹司，梅垣修三：頸部脊柱管拡大術。別冊整形外科 No. 2, 1982, pp. 228-233.

10）小山正信，服部 奨，森脇宣允，新田昭二：頸椎椎弓切 除術の一新術式の試み.中部整災誌 $16: 792-794,1973$.

11）黑川高秀, 津山直一, 田中弘美, 小林正之, 町田秀人, 中村耕造，飯塚 正，星野雄一：棘突起縦割法頸椎脊柱 管拡大術. 別冊整形外科 No. 2, 1982, pp. 234-240.

12）黑佐義郎, 山浦伊裟吉, 中井 修: 頸椎手術後の C5 神 経麻痺の病態。春椎脊䯣 $6: 107-114,1993$.

13) Matsuda Y, Miyazaki K, Tada K, Yasuda A, Na-

kayama T, Murakami H, Matsuo M : Increased MR signal intensity due to cervical myelopathy. $J$ Neurosurg 74:887-892, 1991.

14) Mikawa $Y$, Shikata J, Yamamoto $T$ : Spinal deformity and instability after multilevel cervical laminectomy. Spine 12:6-11, 1987.

15）宮坂 斉, 小林 彰, 井上駿一, 永瀬譲史, 山口清直： 頸椎症性脊䯣症の手術治療成績一前方法の吟味と脊柱管 拡大術の適応. 別冊整形外科 No.2, 1982, pp. 43-50.

16) Nakano N, Nakano T, Nakano K : Comparison of the results of laminectomy and open-door laminoplasty for cervical spondylotic myeloradiculopathy and ossification of the posterior longitudinal ligament. Spine 13: 792-794, 1988.

17）西 幸美, 平林 洌, 藤村祥一，里見和彦，高畑武司， 小野俊明，手塚正樹，河野 亭：片開き式頸部脊柱管拡 大術の長期成績一その意義と問題点. 臨整外 27 : 263-270, 1992.

18) Okada K, Shirasaki N, Hayashi H, Oka S, Hosoya $\mathrm{T}$ : Treatment of cervical spondylotic myelopathy by enlargement of the spinal canal anteriorly, followed by arthrodesis. J Bone Joint Surg $(A m) \quad 73: 352$ $-364,1991$.

19）岡本昭彦，四宮謙一，吉田裕俊，武藤直子，酒井 均, 河内俊行，古谷光太郎，山浦伊乷吉，佐藤浩一：頸椎症 性脊髅症に対する前方固定術後の上下椎間再発例の検 討. 整形外科 $43: 341-347,1992$.

20）斎鹿 稔，河合伸也：頸椎椎弓切除術後の後彎変形。脊 椎脊髄 4 : $551-557,1991$.

21）里見和彦，平林 洌：脊椎固定術後の長期続発症とその 対策. 隣接椎への悪影響. 脊椎脊髄 6 : 203-210, 1993.

22）和田野安良, 林浩一郎：C5 の解剖学的特異性. 脊椎脊髄 6 : 85-92, 1993.

23) White AA III, Panjabi MM : Biomechanical considerations in the management of cervical spondylotic myelopathy. Spine 13:856-860, 1988.

24) Yasuoka S, Hamlet AP, Collin SM : Incidence of spinal column deformity after multilevel laminectomy in children and adults. $J$ Neurosurg $57: 441-445$, 1982.

25) Yonenobu K, Hosono N, Iwasaki M, Asano M, Ono $\mathrm{K}$ : Laminoplasty vesus subtotal corpectomy. A comparative study of results in multisegmental cervical spondylotic myelopathy. Spine 17: 1281-1284, 1992.

旨

\section{頸椎症性脊髄症に対する片開き式頸椎管拡大術について}

谷島 健生 吉益 倫夫 小粥 正博

頸椎管狭窄症による頸椎症性育髄症 25 例に対し片開き式頸椎管拡大術を行い, その問題点を検討し た. 椎弓根部の蝶つがい部には術後 1 年位で十分な骨形成が認められ, 椎らの安定性, 防護性は問題 なかつた．椎らフラップガ頸椎管内に落ち込む合併症が 3 例に認められたが, 時間経過で自然に整復 され骨癒合がみられた．落ち込みによる新たな神経症状の発現もなかつた，後彎变形が 2 例にみられ たが, 神経症状の悪化はなく, 軽度後彎のまま固定した. 症状改善が 20 例, 不变が 4 例であり, 不变

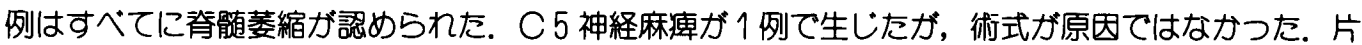
開き式頸椎管拡大術は簡便であり，安全有効な術式であることが判明した. 